\title{
GOD-GODS: ENGAGING AFRICAN CULTURAL REALITIES IN TACKLING SECURITY CHALLENGE IN NIGERIA
}

\author{
Adetunbi Richard Ogunleye \\ Department of Religion and African Culture. Adekunle Ajasin University, Akungba-Akoko, \\ Ondo State, Nigeria.
}

Cite this article: Adetunbi Richard Ogunleye (2021), God-gods: Engaging African Cultural Realities in Tackling Security Challenge in Nigeria. African Journal of Culture, History, Religion and Traditions, 1-14. DOI: 10.52589/ajchrt_WZL7S03 $\mathrm{P}$. https://abjournals.org/ajchrt/ papers/volume-4/issue1/god-gods-engagingafrican-cultural-realities-intackling-security-challengein-nigeria/

\section{DOI: 10.52589/ ajchrt_WZL7S03P}

Received: 17 February 2021

Accepted: 14 March 2021

Published: 18 April 2021

Copyright $\odot 2020$ The Author(s). This is an Open Access article distributed under the terms of Creative Commons AttributionNonCommercialNoDerivatives 4.0 International (CC BY-NC-ND 4.0 ), which permits anyone to share, use, reproduce and redistribute in any medium, provided the original author and source are credited.
ABSTRACT: Various existing studies have shown that the security of life and property is the sine qua non for rapid and sustainable development. However, with reference to Nigeria, insecurity of life and property has been a major challenge. This, therefore, made development seems to be a mirage in the country. Although various attempts to tackle the menace have been made, yet they do not produce the expected result. While the government could no longer guarantee the safety of its citizens citizens' safetyvulnerable to security risk. This paper aims at harnessing and engaging the African (Yoruba) cultural realities to address the unabating security challenges in contemporary Nigerian society. The paper employs primary and secondary data collection methods and adopts historical and phenomenological approaches to achieve the aim. Findings reveal that development cannot emerge in a vacuum; it can only emerge within a secure, peaceful and harmonious environment. The paper is of the opinion that those realities, such as Gog-gods approach and allied realities grounded in African traditions used in pre-modern Nigeria to achieve peaceful co-existence, can still be relevant if applied to the security challenge of this country. Therefore, the paper recommends that indigenous African heritage should not be put aside as a result of modernity; rather, they should be appreciated and be utilized as the solutions that Nigerians are seeking to address the issue of insecurity can be found in them.

KEYWORDS: African Culture, Cultural Reality, Security, GodGods, Alternative Measure 


\section{INTRODUCTION}

Prominent among the challenges that are threatening the very foundation of the world today is insecurity. The world at large and Nigeria, in particular, is presently in a chaotic situation. People live every day of their lives in fear and uncertainty. Terrorists, hired killers, kidnappers, and armed robbers are now taking over. We live in a changing world with multiple and evolving threats to national security, including terrorism, asymmetrical warfare, and social unrest. The news and reports from our daily newspapers, radio and television are shocking and scaring. It is no longer strange to hear horrible news such as: 'Man found with human skull, bone,' (Isigu 2012, 8), 'JTF captures Boko Haram leader Bama in a gun battle,' (Alli 2012, 1), 'Policeman killed in Kano attack,' (Adeyemi 2012, 6), 'kidnapped PDP chief found dead,' (Bashir $2012,58)$, etc. This news gave the impression that all are not well in our society. As the general public is blaming it on poor leadership on the part of the government. On the other hand, the government is blaming it on the 'illicit financial flows in the country' (Nwafor 2019). Now that it is clear that government alone could not single-handedly handle this country's security matter, we, therefore, have to look for alternative (indigenous) means of security grounded in African tradition. This will serve as an alternative measure against security challenges in Nigeria. However, we need to examine the security situation in pre-modern Yoruba land and see how they could cope before we can recommend it for this current dispensation.

\section{Security Matters in Nigerian (Yoruba) Traditional Setting}

The three major ethnic groups in Nigeria: Yoruba, Hausa and Igbo, have their traditional authorities under the headship of paramount rulers known as the Oba, Emir and Obi, respectively. These rulers were the security officers of their domains as they possessed legislative, executive and judicial powers. Their powers were reinforced by religious authority. This agrees with Mbiti (1977) position when he declares that man's relationship with the Supreme Being provides him with a sense of security in the world. In addition to this arrangement, the Yoruba people, who can be found in the south-western part of Nigeria, have put various measures in place to combat crime and insecurity of life and property. Among these measures are Epe (curse), Ibura (trial by ordeal), Aale /Magun (embargo), Imule (Oath/Covenant keeping), secret societies, house arrest by the king, Ifina (barrier) and appealing to God-gods when other means proved abortive. These are spiritual traits that survived foreign influence and domination. As part of solutions, these religious expressions will also enhance human flourishing in a changing society. However, because of this security issue's wider nature, I will like to limit these measures to God-gods approach among the Yoruba people and use the findings as leverage to address the challenge of insecurity in Nigeria.

\section{God-gods and Security Matter in Yoruba Traditional Society}

God (Olodumare) among the Yoruba is seen and regarded as the chief security officer. He is the protector and keeper of his people. Thus, crimes such as stealing, kidnapping, raping, killing, armed robbery, etc., that can lead to insecurity of lives and property, ae immoral or societal crime and religious offences that are punishable by Olodumare himself, who is the Supreme Being. Even, if the offender escaped the human arrest and judgement, he cannot escape the divine sanction. This prompted the Yoruba saying that: 'A mookun se ika, bi oba aye ko ri o, ti orun $n$ wo o'. Meaning; 'you that perpetrate evil under the cloak of darkness, if the earthly king does not see you, the heavenly king is looking at you'. This clearly shows that one cannot escape the judgement of God. 
It is interesting to note here that the Supreme Being while executing his divine judgement, delegates some powers to gods and goddesses who act as his deputies on earth. These are the Orisa (divinities) in charge of various departments with their official portfolios. Orisa among the Yoruba are in three categories; Primordial, deified and natural divinities. Their judgements are adjudged to be royal. Thus, nobody mourns the victims of Orisa's judgement; rather, the Yoruba will even thank them. That is why Sapono (god of Poxes) is referred to as Alapadupe, meaning everyone is thanked for killing the victim.

Prominent among the various gods that the Yoruba often consults over crime-related and security matters are Ogun, Sango and Oya. These Orisa are classified as the hot and temperamental deities who are more harsh, demanding, aggressive and quick-tempered (Tishken et al., 2009, 2). Ogun is the Yoruba god of iron and the tutelary divinity of those who deal in iron and steel, such as farmers, blacksmiths, hunters and drivers (Christopher 1996, 3). The Yoruba strongly believe in the power of Ogun to protect and support his devotees in all their endeavours if they obey his commands. The worship of Ogun has some ethical significance. The worshippers should not involve in criminal activities or swear falsely. They should not tell lies or defraud others. If anybody should commit any crime and swear in the name of Ogun, it is believed that it will happen to him as he has sworn. Thus, to commit a culprit to the punishment of Ogun is a serious thing in Yoruba land (Ogunleye 2008, 40)

In the same vein, a covenant is made before Ogun to prevent crime and insecurity of any kind. Both Oba (king) and Baale (village head) always entered into a covenant with their people before Ogun to avoid tyrannical rule and oppression. Business partners often invite Ogun as a witness while entering into an agreement or contract. This is why the Yoruba often refer to Ogun as a presiding divinity over oath and covenant-making (Abioye 1986, 113). In the Yoruba judicial system, people take their oath to 'speak the truth and nothing but the truth' by kissing a piece of iron, especially a matchet (Eluyemi 1985, 36). Apart from this, when rivals were suspected of evil intentions against each other, they are usually made to swear before Ogun to prevent them from harming each other.

It is therefore believed that anyone who breaks the covenant made before Ogun will come under severe judgement. Such a person will die or be deformed through a gunshot, matchet or motor accident. Because of this, the Yoruba often remind themselves that: 'if one will break covenant at all, it must not be the one with Ogun'.

Another god that Yoruba often consult to prevent and manage crime-related matters is Sango, the god of thunder and lightning. He is also connected with rainfall. He is fierce and hates such acts as stealing, sexual immorality, lying and other criminal activities that can lead to insecurity of life and property. The Yoruba dread Sango as they fear Ogun for his fatal attacks on criminals. He does not condone criminals who engage in activities that can lead to insecurity of life and property. They both, therefore, purify the traditional society of immoral and criminal acts. This claim corroborates the assertion of Durotoye $(2009,152)$ that 'Sango is an embodiment of justice.' By and large, Sango still remains a popular and living Orisa that people often consult when in need of 'quick justice dispensation' (Durotoye 2009, 153). In fact, according to Durotoye $(2009,153)$, 'the awesome essence of Sango as the principle of justice is evident among the Oyo Yoruba.'

Finally, among the selected Orisa that deals with criminals is Oya, the river goddess. She is identified with River Niger. Tornadoes are attributed to the wrath and anger of Oya in 
collaboration with Sango, who happens to be her husband. Her emblems are two swords and the horn of a buffalo (Adewale 1988, 33).

With this traditional arrangement, the ugly situations of insecurity of life and property due to the political, religious and terrorist attack under the cloak of religion were not as rampant in antiquity as they are today. With reference to security in traditional society, there was religious tolerance and mutual understanding. African religion is always forbearing, and tolerance is its hallmark (Dime 1993, 150). It is this attribute that promotes both religious and political harmony in a traditional African setting. Despite the various numbers of sects such as Igodo, Sango, Ekpe, Olokun, Orunmila, Ala etc., there was peace and harmonious relationship among the people. However, with the emergence of the government's western system, new and formal approaches were adopted as measures against security challenges. The kind of political killing, terrorism, insecurity of life, religious animosity, and frictions that are rampant today in the Christian and Muslim communities were absent in the good olden days.

\section{Security Challenges in Modern Nigeria}

Security, whether of a nation or an individual, is a cherished value related to the physical safety of individuals, groups or nation-states (Nnoli 2006, 16). It also involves the safety of their most cherished values. It, therefore, implies freedom from all forms of threat, anxiety and danger. It is what any government or an individual desires to have. Thus, any political entity's beauty lies in its ability to provide adequate security for its people's life and property. The provision of security for life and property in a society enhances public peace and mutually productive lifeways. In addition, where there is safety, development is automatically arrested (Abegunde 2013, 228). However, the growing conflicts between religious groups, terrorists' attacks from Boko Haram, and incessant kidnapping have exerted a devastating effect on Nigerians' safety and security. Right from the beginning of the year 2009, there have been several attacks by these groups, which led to the loss of several lives and left some maimed for life. The government's inability to deter, defeat and respond decisively to terrorist attacks is the most challenging priority facing Nigeria today.

From villages to cities, Nigerians lament bitterly about the insecurity of life and property in the country. No place is left untouched. Even some Nigerians that were outside the country were afraid to come home. It is no longer news that the British and American governments are routinely warning their citizens about where not to go in the country (The Nation 2012, 19). Nigerians have been going through these horrible experiences since Boko Haram's terrorism has led to the deaths of thousands of innocent Nigerians. There is hardly a day that is free of shooting. Among the bitter experiences of Nigerians is the several bombing of places of worship, market places, the United Nation building, Police Stations, Independent National Electoral Commission (INEC) offices, and many other audacious attacks that give the impression that Nigeria is in a state of anarchy (The Nation 2012,19). Security is a very serious and sensitive issue that must not be politicised. It is to be noted here that despite this terrible situation, the country's president is still assuring the citizens that the country is 'safe and secure' and that the country's security challenges are under control (The Nation 2012, 19). People could no longer sleep with their both eyes closed; they could no longer walk freely or travel at night. Houses and banks are no longer safe from the incessant robbery attacks. Schools and even roads are equally not safe. The burning issue of abduction of over 200 school girls who are yet to be released since April 2014 is still lingering in many Nigerians' hearts. We are 
only sure of the present minute; nobody can say categorically what would happen the next minute.

As if these were not enough, on the 10th of December, 2012, it was widely reported in nearly all the Nigerian dailies that the octogenarian mother of the former Federal Minister of Finance, Ngozi Okonjo-Iweala, was kidnapped and bundled into a waiting vehicle by gunmen numbering about ten on that fateful Sunday afternoon (The Nation 2012, 4). Now, if the mother of a minister of the whole country is no longer safe, I wonder what would happen to commoners on the street. Coupled with the crime of kidnapping are the various cases of rape. In real sense, this is the crime of forcing a woman or a girl to have sex with a man she has no intention and desire to have sex. Rapist in our society had produced a sense of libel, detention of character, dehumanisation, degradation, shame and embarrassment. As reported in the Citizen Newspaper of Johannesburg:

Rape is so rampant that it overtakes away other health risk posed to this country's women and, increasingly, to its children as well... The rape of children has doubled in recent times... these acts are committed seemingly in perpetuating the myth that an HIV/AIDS carrier who rapes a virgin will be cured (Citizen 2012, 4).

This act has led to the harassment of women and girls in our society. Victims of human traffickers also narrated their ordeal of rape, horror and brutality during an encounter with them at a forum on Modern Slavery. They shared their experiences as unsuspected female victims of human trafficking that had been given the lure of a better life in Europe. Instead, according to Miss. Isoke Aikpintayi, "They beat us and brought in some men to rape us, cut us with blade and made us suffer" (The Nation 2012, 2-3). This account is one of the revelations made at a two-day workshop organised by the women's Optimum Development Foundation (WODEF) held in Ibadan, Oyo State, Nigeria.

Even the former Nigerian senate president, David Mark, while taking stock of the unabating security challenges facing the nation, lamented and called for soul searching among Nigerians in a bid to get a permanent solution to the crisis. He noted that the situation had degenerated to an intolerable level that exposes everybody to danger (Nigerian Tribune 2013, 3). The recent \#EndSARS protest in Nigeria is a confirmation of this unbearable situation in the country. The protest, organised and staged by the Nigerian youths, was a peaceful one demanding an end to police brutality, extra-judicial killing and extortion by the Special Anti Robbery Squad (SARS), a unit of the Nigerian Police saddled with the responsibility of fighting violent crime. On the $20^{\text {th }}$ of October, 2020, the Nigerian soldiers and police opened fire on the peaceful protesters at the Lekki Tollgate in Lagos, where about 78 protesters were killed (Lawal \& Mark 2020). This is the precarious situation that Nigerians found themselves in their country. It beats the imagination of any person to accept the fact that the security outfit in Nigeria is unable to put an appropriate resistance to security challenges in the country as the police officers were telling the public to find an alternative means of protecting themselves because they could not guarantee security during the approaching Christmas and New year festivals (Omonibi 2020). To curb or at least minimise the menace of insecurity in this country, all hands must be on deck. Before any solution can be proffer for any problem, the causes must first be identified. Now, what are the agents and causes of insecurity in Nigeria? 


\section{Agents of Insecurity in Nigeria}

Today, insecurity has assumed a new dimension. It has grown and gone global. Thus, no man or woman is secured or immune from this modern form of unrest (Echiegu 2012, xiii). Various agents have been discovered to be behind the incessant security risk in Nigeria. Prominent among the agents in this country is unemployment, and it has become one of the significant challenges facing Nigeria today. It is now a global problem as both developed, and developing countries are facing the same problem. Because people are not gainfully employed, they take to criminality, leading to the insecurity of life and property in the country (Ogunleye, 2012, 110). There are some people today who are university graduates but cannot find employment opportunities. They are roaming about the streets doing nothing. Since an idle hand is a devil's workshop, they occupy themselves with crimes of all kinds.

Coupled with unemployment is poverty. This is a serious phenomenon as it goes hand in hand with violence, bribery and corruption. Though, poverty from the African perspective is a social condition that was intolerable and rejected as a way of life (Olupona 2009, xxii). Yet, a larger percentage of Nigerians are wallowing in abject poverty. Even those that are working are not different as they could not get their salaries from their employer. According to his observation, Bouvier $(1985,113)$ pointed to our time's social reality. He said, among other things, that, 'today the poor are no longer individuals, but entire nations that become increasingly poor'. It is unfortunate to hear that, despite the fact that Nigeria is the third biggest economy in Africa, Nigeria is 'ranked 160 out of 177 countries on the Human Development Index (HDI) scale (Poverty in Nigeria, 2013,1). Poverty therefore led many Nigerians to engage in criminal activities that made them threats to their various communities and nation at large.

The third one is religious fanaticism. According to Hornby, the term 'violent, unreasoning enthusiasm' (Hornby 1984, 309). By this, we simply mean religious claims to absoluteness. It implies that one's religion is the best that gives assurance of salvation to man. This is the exact position of Boko Haram in Nigeria today. Boko Haram has been associated with segregative ideology and violence to humanity because of its philosophy of 'hate and discrimination' against other cultures that are basically non-Islamic (Nwanaju 2012, 35). Religious fanaticism in Nigeria has reached a dangerous dimension as Boko Haram- an Islamic sect is hell-bent on the total destruction of other groups in the country. The sect is not ready to tolerate others who do not think and feel the way they do. They believe, though wrongly, that 'those who do not share their mode of worship or the doctrine of their religion were better dead than alive' (Mala 1985, iii).

Coming next is the political undertone. This has to do with the inordinate ambition of our politicians in the country. Politics in Nigeria is taking a dangerous dimension. The average politician sees politics as a shortcut to instant wealth. Thus, they pursue it with a 'do-or-die approach. Their major aim is to amass wealth as much as they can and save up much money to fight future elections so that they can continue to be the choice of their constituencies for political posts (Adesina 2005, 37). It is on record that religion is fast becoming one of the ready weapons that are often manipulated by self-seeking leaders (Adiele 1993, 207). With this situation, it would not be out of place to argue, according to Nwanaju that, the motive of the Boko Haram is not a spiritual uplift of Muslims, but a craze for political leadership and domination over the people (Nwanaju 2012,38), From what has been discussed above, one can see that some of the religious crises that had been experienced in Nigeria were more of political 
than religious. Therefore, it is necessary for the masses that are being used to know that those who claim to be championing their course are not without hidden motives (Adiele 1993, 204).

Another major cause of insecurity is unguarded and reckless utterances. This often fuels the flame of riots that usually lead to the insecurity of life and property. Because Nigeria is made up of people of diverse religious backgrounds, one may not be surprised that it is a pluralist religious state. In a pluralist religious state like Nigeria, one expects a preacher to preach the idea of the religion and leave his audience to compare with those of other religions and make their choice. However, because of the inbuilt weaknesses in a pluralist religious state, manipulators tend to cash on religion's sensitive nature to create confusion (Adiele 1993, 1). Some preachers even dabbled into the doctrine of other religions, distort facts and misrepresent its teaching to impress the audience. Many conflicts that could have been averted were experienced as a result of reckless publications and unguarded utterances. In recent time, some religious and political groups have gone to the extent of having their radio stations, newspapers, and magazines to publish their provocative articles (Sheriki 1993, 93).

Furthermore, electoral manipulation is another source of crisis that often leads to the insecurity of life and property. Cases abound throughout the country where electoral results were falsified and manipulated by electoral officials. For instance, the recent gubernatorial elections in the various parts of the country were allegedly characterised by a series of manipulations and other electoral malpractices. In his lamentation, the Vicar General of the Catholic archdiocese of Jos, Reverend Father Cletus, condemned the political class for making the road towards hitch-free and successful elections hazardous. Therefore, he was disappointed that the phenomena of personal antagonism, thuggery, intolerance, character, and physical assassination still featured in the country (Nigerian Tribune 2006, 6).

Other similar agents of insecurity are the creation, location and relocation of local government secretariats. Many lives have been wasted, and properties worth millions of Naira had been destroyed due to disagreement over the local government secretariat's location and relocation. The creation of Ife East Local Government in the state of Osun in 1999 witnessed an actual state of life and property insecurity. The sanctity and respect for human life were thrown overboard. It then became the survival of the fittest.

Last but not least is the grievances as a result of perceived marginalisation. When certain groups of people or communities felt that they were being marginalised, either by the government or by another tribe or group of people, there is a possibility that a crisis will come up. For instance, there have been constant violent conflicts in the Niger Delta area in Nigeria because the Ogoni people in that area felt that they were being marginalised and not being given a fair share of the country's primary source of wealth - petroleum and gas. Unfortunately, their agitation was met with the deployment of military and state security officials who quelled the violent reactions and inflicted physical pains on them (Okeke, 2012, p. 79).

\section{Past Attempts towards Curbing Security Challenges in Nigeria}

Various efforts have been made in the past to overcome security challenges in this country. Both government and the general public have tried their efforts, but the menace seemed unconcerned. Among the efforts made so far is the general appeal to the populace by the wellmeaning Nigerians to 'give peace a chance', 'allow peace to reign', etc. Others include police officers' drafting to the scenes of the crises to put the situation under control. This often ushered 
in police brutality, and at times, several of the rioters got killed or wounded (Otite 2001, 302). This strategy's effect is ephemeral as rioters usually return to the street on the following day to continue their violence. Another means of trying to curb security challenges in the past is the establishment of a commission of inquiry to investigate the causes of such conflicts to bring the culprit to book (Otite 2001, 302). From past experience, such commission results never see the light of the day before another conflict starts.

It is unfortunate to hear that none of the efforts mentioned above has a lasting and effective grip on the situation. In present-day Nigeria, no day passes without fresh news of carnages and senseless killing of innocent citizens. Living in Nigeria has become a hazardous enterprise as the country is in the throes of war (Nigerian Tribune 2013,13). Above all, one would not be surprised to hear that, despite the failure of the federal government to address the issue of security challenges, the former president of this country, Dr Good luck Jonathan, is still assuring us that the country is safe and that the security challenges are under control, while in actual sense, we all know that government has always been appeared helpless and groping under the ghost of terrorists and other criminals that have turned Nigeria into a hell on earth (The Nation 2012, 19).

Now that it is very clear beyond any reasonable doubt that the government could not singlehandedly handle the security challenges in this country, and since the best of the various agencies saddled with the security matter of this country has not been enough, the situation, therefore, calls for alternative means to complement the effort of traditional agencies, so that a peaceful atmosphere can be realised. The submission of Chris Stringer \& Robin Mckie, as cited by Curtis Keim $(2014,6)$, agrees to this when they write that 'the key to modern humans' evolution was our development of new ways of thinking'. It is believed that this alternative measure will go a long way in curbing and reducing the crime rate to the barest minimum in Nigeria.

\section{The Relevance of Indigenous Measures in Curbing Security Challenges in Nigeria}

The crime of various forms and levels has been the major challenge to contemporary Nigerian society. Every attempt to bring the wave under control proved abortive. However, before the contact with western civilisation, the Yoruba people have put in place some indigenous measures and institutional mechanism to curtail crime and criminal activities in their social life. The impression, therefore, is that crime control in traditional Yoruba society appears to have been more effective than crime control in present-day Nigeria. This indigenous measure is relevant and will be useful if adopted for possible inclusion in our extant security scheme as complementary.

First and foremost, this indigenous measure will promote tolerance within a peaceful environment. In this country, we need to tolerate ourselves irrespective of whether we belong to the same religion, ethnic and political group or not. Tolerance in this context refers to a religious man, politician or man from different ethnic groups to give allowance for the opinions of other people's beliefs and practices (Ayantayo 2002, 78). It is apparent that Nigerians have been witnessing predominantly Christian/Muslim conflicts since independence which gives an impression that indigenous worshippers are not part of the Nigerian population (Alana 1993, 207). Nevertheless, it is interesting to note here that peace-making is a major task of indigenous religious functionaries. In the observation of Rweyemamu, he said, among other things that: 
In African Traditional Religion, peacemaker represents divine power on the one hand and social harmony on the other. In his person, he expresses the divine origin of peace, a peace that is associated with the virtue of loyalty, honesty and trust in God (Rweyemamu 1989, 384).

If Nigerians and their leaders can emulate traditional religion adherents in embracing peace, then Nigeria will be a paradise on earth. Still, on the spirit of tolerance in African Religion, Dime has this to say;

One of the greatest virtues of African Religion (Afrel) is its religious tolerance. There is hardly any religion in the world that teaches religious tolerance, as does African Religion. It teaches it not so much by precept as by practices, that is, by example (Dime 1993, 146).

The above quotation shows that African religion, which is the source of inspiration for traditional authority, has something good to offer the entire Nigerian populace. If people can borrow a leaf from it, the religion (Afrel) will encourage citizens to constantly embrace the spirit of acceptance and accommodation of divergent views.

Secondly, traditional rulers' mediating roles in conflict management can also help curb insecurity of life and property in Nigeria. As the pontifix maximus (Highest Priest), traditional rulers are their peoples political and religious leaders. They are, therefore, the chief security officers of their respective communities. They possessed legislative, executive, and judicial power. This made them to be seen as the ones "to whom all heads bow, and before whom all knees bend" (Nabofa 1999, 36). At a reception in honour of the pioneer Director-General of the Federal Capital Territory (FCT), Chief Gordian Oranika, the traditional ruler of Abatete in Idemili North Local Government area of Anambra State, Chief Charls Emeka Ofobi advocated for the inclusion of monarchs in the security strategy adopted to check insecurity in the country. This is because the criminal elements are better identified at the local level and can be easily isolated by community leaders. He added:

In every community, those in it know exactly what is going on. If you have criminals in your community, they are brothers and sisters of people. If we are sincere to ourselves and if we can identify the bad eggs in our various communities, all these problems will stop (Efobi 2013).

This community-supported initiative will go a long way in curbing terrorism, insurgence and kidnapping menace in some parts of the country. Through this, peace and harmonious relationship, which is the goal of all moral conduct, shall be attained.

Thirdly, creation of the 'Committee of Community Leaders,' which is one of the structures of traditional government, will be of great help in checking insecurity in Nigeria. Members of this committee will include; traditional rulers, chief priests, chiefs and clan heads. It will be part of this committee's responsibilities to teach the youth of their communities the moral and human values as enshrined in their religion and culture. Speaking on 'The Role of Religious Leaders and Traditional Rulers in the quest for national security and peace,' the Emir of Dass, Alhaji Usman Bilyaminu, expressed dismay that traditional institutions were not integrated into various security committees at the federal, state and local government levels (Bilyaminu 2012). The monarch added that, since traditional rulers know virtually everyone living in their domains and no activity can be carried out within the community without their knowledge, it 
is therefore easy for them to supervise community policing (Bilyaminu 2012). Traditional rulers' efforts in conflict management in the past have shown that they are up to the task.

Moreover, appreciation of both human and moral values as enshrined in the African culture will guide our media houses to publicize their activities. This will guide them to be objective in discharging their duties so as not to cause confusion. There are some cases where some public newspapers are used to disseminate their information and messages that have led to crises in various parts of the country. Before any programme could be placed on air, it should be carefully edited since, in some cases, what is seen and heard often determines how people react to issues. Therefore, it is advisable that the programme that will depict peace and African cultural values as embedded in indigenous religion should be encouraged and promoted.

Also, the measure will promote an enabling environment for a job opportunity in the country. The traditional Yoruba environment does not tolerate idleness. Both the young and old must put their hands on something worthwhile. The Almanjiri (unemployed youth) in the northern parts of the country must rethink their actions and not allow themselves to be used by selfish politicians to fuel crises. From the viewpoint of African Traditional Setting, 'an idle hand is the devil's workshop.' Thus, there is no room for loiterers or idlers in the Nigerian community in antiquity. It is believed that when people are gainfully employed, the menace of religious, political or ethnic conflict that often leads to insecurity of life and property will be reduced to the barest minimum.

Furthermore, invocations of God-gods will conscientise public office holders so that they can realise the importance of their oath of office and the consequences of breaking such oath. The awareness of this reality will encourage public office holders to dispense their duties without fear or favour and, at the same time, be alive to their responsibilities. Thee same vein will be useful in addressing the evils of corruption, abuse of office, oppression, and money laundering prevalent in the country. The reality on ground is that people in authority seem unable to enforce the highest degree of moral and religious truth demanded by this age. This, no doubt, has caused a major setback to the country's socio-ethical development, political stability, and cultural development. The importance attached to a covenant made before one divinity or the other in the traditional Yoruba community always remind people in authority of the consequences of violating their oaths of office and that of allegiance.

Finally, the inclusion of indigenous security operatives in this country's security strategy will be of immense help in curbing security challenges. These security operatives are traditional hunters and vigilante groups that see their respective ethnic groups' safety. Members of these groups derived their strength from the traditional religion of their localities. Prominent among these groups is the Oodua People's Congress (OPC), founded in the Yoruba southwestern region of Nigeria due to what was perceived as the Nigerian police's failure to combat crime. They served as security guards and tried to protect the territorial integrity of their ethnic group. In the eastern part of Nigeria, 'The Bakassi Boys' is known as the popular indigenous vigilante group. Like OPC in Yoruba land, the group tends towards total eradication of security threat in the region. Likewise, we have 'Egbesu Boys' and Amotekun, the newly inaugurated security network of south-west Nigeria.

Although hese indigenous operatives may go out of hand and overreact at times, this does not invalidate their formation's original purpose, which is to see to the safety and security of their ethnic groups. Since anything can be abused, a case in point here only indicates that the 
indigenous operatives have been put into wrong use. It should also be noted that the importance of these indigenous operatives overwhelmed their weaknesses.

Other African countries such as: Cote d'ivoire, Sierra-Leone, Kenya, and so on have tried it and found it effective. In the 1990s, when a crime wave overtook Cote d'Ivoire, and the Ivorian police failed to control the situation, it was a 'Benkadi Movement' that took up the role of people's protector. Members of this movement were Dozo-hunters, skilled in ritual sacrifice. This movement connected the spiritual and the mundane to allay the fear of insecurity in their country (Hellweg 2011). Also, in Sierra-Leones Poro and Bundu societies regulated social behaviour and mediated daily life crises for average Sierra-Leoneans (Lynda 2012, 17). As for the people of Kenya, Mau-Mau's role during their trying period cannot be quickly forgotten.

\section{CONCLUSION}

Although Nigerians have been facing a series of challenges ranging from economic to political, yet that of insecurity is the one that is threatening the existence of the country. Various operative measures that were put in place to suppress this security threat proved abortive. Having discovered that government alone could no longer guarantee its citizens' safety and that the various security agents are at their wit's end, this paper, therefore, suggested an indigenous approach as an alternative means of handling security matters in this country. Divinities have played a vital role in the security matters of the traditional Yoruba society. For example, Sango (the Yoruba god of thunder) is often employed to strike down people who are considered a security threat to society. Ogun, the Yoruba god of iron and other divinities, are not left out as they could be invited to deal with criminals and protect the community from evil-minded people.

However, the neglect of these divinities in our contemporary society has worsened the security situation in Nigeria. Nevertheless, suppose true adherents of these divinities are sorted out and employed to complemenof our modern security operatives' effort such as soldiers and police officers. In that case, Nigeria will boast of adequate security and make those threatening the nation's security to pay heavily for it. This is possible because the culprit cannot escape the divinities' searching eyes that have been tested and confirmed to be effective in fishing out and punishing criminals. In addition, the involvement of traditional rulers as the chief priest and security officers of their communities, religio-cultural organisations such as: OPC, Bakassi Boys, Egbesu Boys, Amotekun group, etc., and other traditional means of maintaining law and order will usher in the wind of change to security matters in Nigeria.

Some African countries such as Cote d' ivoire, Kenya and Sierra-Leone have done it, and it worked for them very well. It is therefore recommended in this paper that Nigerians should borrow leaf from other African countries and adopt traditional approach as a supplement in tackling their security challenges. It is believed that, if this approach is adopted, the solutions that Nigerians are seeking for to address the issue of insecurity will be find in it. Consequently, there will be a peaceful and harmonious relationship in the country and the government at all levels will be able to deliver good governance. 


\section{REFERENCES}

Abegunde, O. 2013. 'Need For Security Sector Reform: Nigerian Perspective.' International Journal of Humanities and Social Sciences. Vol.3 (9).

Abioye, A. 1986. 'Advanced Studies in West African Traditional Religion for Higher Schools.' An unpublished book.

Adesina, S. O., 2005. 'The Christian Theology of Righteousness and its Implication for Nigeria Today.' Journal of Religion and African Culture. 1, (1).

Adewale, S. A. 1988. 'The Religion of the Yoruba: A phenomena logical Analysis, Ibadan: An unpublished book.

Adiele, S. N. 1993. 'Religious Crisis in Pluralist Religious State: A Christian Perspective,' Abubakre, R. D. etal Eds. Studies in Religious Understanding in Nigeria. Ilorin: NASR.

Alana, O. E. 1993. 'The Relationship between Christians, Muslims and Afrelists in history, with particular Reference to Nigeria.' Abubakre, R. D. etal Eds. Studies in Religious Understanding in Nigeria. Ilorin: NASR.

Ayantayo, J. K. 2002. 'Matters Arising from Unhealthy Religious Relations in Nigeria: A Moral Appraisal.' Babalola, E. O. Ed. African Cultural Revolution of Islam and Christianity in Yoruba land. Lagos: Eternal Communications Ltd.

Bilyaminu, U. cited in 'NOA Partners Traditional Rulers in Peace building,' (A Peace Building Forum in Kastina state). 21st December, 2012.

Bouvier, P. 1985. 'The Mission of the Churches amid the Social Reality of Rich and Poor Nations.' Frederick, F. and Mataragnon, R.H. (Eds), God and Global Justice; Religion and Poverty in an Unequal World. New York: Paragon House, 1985.

Christopher, S. 1996. Ifa: African god speaks. Hemburg: litverlas.

Citizen Newspaper. Cited in Awake! 8th November, 2012.

Dime, C. A. 1993. 'Service through Tolerance- The way of Afrel,' Odumiyiwa, E. A. and Opeloye, M. O. Eds. Religion and service to Humanity. Ilorin: NASR.

Durotoye, A. A. 2009. 'Reconfiguration of Sango on the Screen.' Tishken, J. E. etal. (Eds). Sango in Africa and the African Diaspora. U.S.A: Indiana University Press.

Echiegu, A. O., 2012. 'Foreward.' Anyanwu, S. O. and Nwanaju, I. U. Eds. Boko Haram and Terrorism: Religious Conflicts and Dialogue Initiatives in Nigeria. Enugu, Nigeria: SNAAP Press.

Efobi, C. E. 2012. Cited in 'Nigeria: How Traditional Rulers can help curb Insecurity.' Available at http://allafrica.com/stories/201212100481.html. Accessed on the 15th January, 2013.

Eluyemi, O. 1985. This is Ile-Ife. Ile- Ife: Ogboru Press.

Hellweg, J. 2011. Hunting the Ethical State: The Benkadi Movement of Cote d'ivore. Chicago: The University of Chicago Press.

Hornby, A. S. 1984. Oxford Advanced Learners' Dictionary of current English, Oxford: OUP.

Keim, C. 2014. Mistaking Africa: Curiosities and Inventions of the American Mind. USA: Westview Press.

Lawal, S. \& Mark, M. 2020. 'A Dozen Protesters in Nigeria Reported Killed by Security Forces.' The New York Times. Available at www.nytimes.com. Accessed on 1st November, 2020.

Lynda, Day. 2012. Gender and Power in Sierra-Leone: Women Chiefs of the Last two Centuries. USA: Palgrave Macmillan. 
Mala, S. B. 1985. 'Fanaticism in Religion: A Naughty Child of Difficult Mother.' Orita: Ibadan Journal of Religious Studies. xvii/2.

Mbiti, J. S. 1977. African Religion and Philosophy. London: Heineman Publication.

Nabofa, M. Y. 1999. 'Theocracy and Democracy from the perspective of African Traditional Religion.' Orita: Ibadan Journal of Religious studies. Xxxii.

Nigerian Tribune, 'Nigeria: The war within.' Monday, 13th May, 2013.

Nigerian Tribune, 'Security Challenges: Perpetrators are Nigerians'. Monday 13th May, 2013.

Nigerian Tribune. 'Road to 2007 election Hazardous.' 13th September, 2006.

Nnoli, O. 2006. National Security in Africa. Enugu, Nigeria: SNAAP Press.

Nwafor, Sunday. 2019. 'Illicit Funds Fuel Insecurity in Nigeria, Africa.' https://www.vanguardngr.com/2019/17illicit-fund-fuelinsecurity-in-nigeria-africabuhari

Nwanaju, I. U. 2012. 'Boko Haram and Violence Halal.' Anyanwu, S. O. and Nwanaju, I. U. Eds. Boko Haram and Terrorism: Religious Conflicts and Dialogue Initiatives in Nigeria. Enugu, Nigeria: SNAAP Press.

Ogunleye, A. R. (2012). 'Religion, Peace and Conflict: An Assessment of the Role of African Religion Towards Conflict Management in Nigeria.' Ayantayo, J. K. etal (Eds).

Religion and Governance in Nigeria. Ibadan: Dept. of Religious Studies, University of Ibadan.

Ogunleye, A. R. 2008. 'Covenant-Making in Yoruba Traditional Religion: A Panacea for Moral Decadence in Nigeria.' A PhD Thesis, Dept. of Religious Management and Cultural Studies, Ambrose Ali University, Ekpoma, Edo state, Nigeria.

Ogunleye, A. R. 2011. 'Traditional Authorities in Nigeria: Relevance and Challenges,' African Journal of Cultural, Religions, Educational and Environmental Sustainability. 1,1 .

Okeke, U. R. 2012. 'Government Ethics and the Management of Environmental Conflict in Ogoniland.' Ayantayo, J. K. et al. Eds. Religion and Governance in Nigeria. Ibadan: Department of Religious Studies. University of Ibadan, Ibadan.

Olupona, J. 2009. 'Understanding poverty and its alleviation in Africa and the African Diaspora: An interdisciplinary Approach.' Peter, J. Paris (Ed). Religion and Poverty: Pan-African Perspectives.USA: Duke University Press.

Omoni, K. 2020. '\#EndSARS: We Can't Guarantee Security during Yuletide.' Available at www.vanguardngr.com. Accessed on $2^{\text {nd }}$ November, 2020.

Otite, O. 2001. 'On Conflicts Resolution, Transformation and Management.' Otite, O. and Olawale, I. Eds. Community conflicts in Nigeria: Management, Resolution and Transformation. Ibadan: Spectrum books Limited.

Poverty in Nigeria: Rich country, poor people'. http://www.poverties.org/poverty-innigeria.html

Rweyemamu, R. 1989. 'Religion and Peace (An Experience with African Traditions).' Studia Missionalia. 38.

Sheriki, A. 1993. 'The Nigerian Society and Religious Conflicts: A Retrospective view.' Odumuyiwa, E. A. \& Opeloye, M. O. Eds. Religion and Service to Humanity. Ilorin: NASR.

The Nation. 'Jonathan Orders Rescue of Okonjo-Iweala's Mum.' 11th December, 2012.

The Nation. 'JTF capture Boko Haram leader Bama in a gun battle.' 22nd June 2012.

The Nation. 'Kidnapped PDP Chief found dead.' 22nd June, 2012.

The Nation. 'Man held with human skull, bones.' 23rd January, 2012. 
The Nation. 'Police man killed in Kano attack.' 22nd June, 2012.

The Nation. 'Redefining Safety'. 11th December, 2012.

The Nation. 'They beat us, Raped and cut us with blade.' 23rd November, 2012.

Tishken, J. E. etal. Eds. 2009. Sango in Africa and the African Diaspora. U.S.A: Indiana University Press. 